\title{
ENGLISH IN PRACTICE
}




\title{
English in Practice
}

\author{
F. E. FODEN \\ B.Sc. (Econ.), M.ED., PH.D. \\ Head of the Department of General Education \\ Loughborough Technical College
}

\section{Macmillan Education}


ISBN 978-0-333-15842-5 ISBN 978-1-349-02188-8 (eBook)

DOI 10.1007/978-1-349-02188-8

(C) F. E. Foden 1974

Reprint of the original edition 1974

All rights reserved. No part of this publication may be reproduced or transmitted, in any form or by any means, without permission

First published 1974 by

THE MACMILLAN PRESS LTD

London and Basingstoke

Associated companies in New York Dublin

Melbourne Johannesburg and Madras

SBN 333158423

Typeset by
Computatype (UK) Ltd. Fort William 


\section{CONTENTS}

Preface and Acknowledgements ix

Introduction xiii

Activity and Discussion, xvi

1 GETTING AND GIVING INFORMATION 1

Facts, 3

Activity and Discussion, 4

Fiction, 6

Criticism in Practice, 7

Ideas and Beliefs, 11

Activity and Discussion, 12

Getting and Giving Information, 14

Activity and Discussion, 15 - Criticism in Practice, 17

Exercises, 24

2 GETTING INFORMATION FROM READING

Reading - Mastering Difficulties, 28

Criticism in Practice, 29

Mastering Words - a Good Vocabulary, 35

Activity and Discussion, 37 - Criticism in Practice, 39

Reproducing Information and Ideas - 'Comprehension', 43

Criticism in Practice, 44

Inferences and Conclusions, 48

Activity and Discussion, 49 - Criticism in Practice, 50

Answering Comprehension Questions, 53

Exercises, 54

3 OTHER SOURCES OF INFORMATION - PICTURES,

DIAGRAMS, STATISTICS

Pictures, 65

Activity and Discussion, 66 - Criticism in Practice, 72

Diagrams, 74

Criticism in Practice, 75

Statistics, 86

Exercises, 87 
4 REPORTS: VERBATIM AND SUMMARY

Verbatim Reports, 95

Activity and Discussion, 96

Making Notes - Notes for Guidance, 97

Activity and Discussion, 98 - Exercises, 101

Summaries and Abstracts - Notes for Guidance

I: Analysis and Understanding, 103

Exercises, 105

Notes for Guidance II: Condensation, 108

Exercises, 110

Notes for Guidance III: Composition, 119

Exercises, 121

Minutes - Notes for Guidance, 127

Activity and Discussion, 129

5 REPORTS: DESCRIPTIVE, ANALYTICAL, EXPLANATORY

Criticism in Practice, 135

Notes for Guidance I: Purpose - Terms of Reference, 143

Activity and Discussion, 144

Notes for Guidance II: From Whom? To Whom?, 146

Criticism in Practice, 148

Notes for Guidance III: Formal Presentation and Layout, 151

Activity and Discussion, 154 - Criticism in Practice, 155 - Exercises, 159

6 COMMUNICATION DIRECT: LETTERS, MEMORANDA,

TELEGRAMS

Letters Personal, 162

Activity and Discussion, 163 - Criticism in Practice, 165

Letters Public, 174

Criticism in Practice, 176

Letters: Business and Official, 181

Notes for Guidance I: Superscription, 182

Notes for Guidance II: Subscription, 185

Notes for Guidance III: Envelopes, 187

Notes for Guidance IV: Body of the Letter, 189

Criticism in Practice, 191 - Exercises, 195

Memoranda, 198

Activity and Discussion, 199 - Criticism in Practice, 200 - Exercises, 203

Telegrams, 204

Notes for Guidance: Drafting and Sending Telegrams, 205

Exercises, 206 
7 COMMUNICATION DIRECT: NOTICES, ANNOUNCEMENTS, INSTRUCTIONS, ADVERTISEMENTS

Notices, Announcements, Warnings, 209

Activity and Discussion, 210

Notes for Guidance in Writing Notices and

Announcements, 211

Criticism in Practice, 212

Instructions and Notes for Guidance, 220

Activity and Discussion, 222 - Criticism in Practice, 223

Advertisements, 228

Criticism in Practice, 229

Filling in Forms, 230

Exercises, 231

8 EXPRESSIVE WRITING

Activity and Discussion, 236 - Criticism in Practice, 238

Essays, 246

Criticism in Practice, 248

Notes for Guidance I: Content - What the Essay is about, 252 Activity and Discussion, 254

Notes for Guidance II: Language, 257

Criticism in Practice, 258

Notes for Guidance III: Form and 'Mechanics', 260

Exercises, 263

Extended Essays, 266 


\section{PREFACE AND ACKNOWLEDGEMENTS}

English in Practice is a Programme, not another textbook. Most students using the Programme have worked through textbooks either in school or college and will probably not welcome yet another progress through the traditional chapters, however cheerful and fresh their contents. It enables them to follow a connected, coherent course suited to their immediate social needs, consisting of elements chosen from a very wide selection of reading material, notes for guidance and exercises.

Sections are designed to cover various areas of practice in the essential elements, conventions and skills of communication which concern students in courses related to technical, professional and business studies, both preliminary and more advanced. These include:

GetTing and Giving Information

GetTINg INFORMATION FROM READING AND Other SOURCES

\section{Report-Writing and TeChNiCAL Description \\ LetTers and Office Communications \\ Notices, Announcements, Instructions \\ EXPRESSIVE WRITING}

The Programme is concerned not only with strictly vocational applications of communication skills. Many of the exercises in all sections have also a general, social or non-vocational reference, and may perhaps be attempted as much for pleasure as for practice. The section on Expressive Writing contains suggestions and exercises less specifically related to definable vocational needs than the rest, though the work here has a close bearing on some of the conventional kinds of writing called for in English examinations.

In fact, the entire Programme of work contained in English in Practice can be regarded as providing suitable and adequate practice for most of the examinations in English and Communications normally taken by students in 16-plus courses, ranging from the Certificate of Office Studies, through the many 'external' examinations set by the Regional Examining Unions,* the Royal Society

* The East Midland Educational Union, the Union of Educational Institutions, the Union of Lancashire and Cheshire Institutes, the Northern 
of Arts and other bodies, Ordinary National Certificates and Diplomas in Business Studies and Public Administration and, on the technical side, the Ordinary National Diploma in Technology. It should also be of direct value to students on Certificate of Extended Education courses when these develop. As new assessment programmes in technical and business studies courses containing a communication element are likely to emerge in the near future and this Programme should be applicable to these also. Students on some of the more advanced courses, especially those leading to Higher National and comparable diplomas and certificates, may also find useful material from which to quarry.

The work contained in the Programme is not graded in any conventional way. Most of the reading material can be appreciated at different levels and exercises can be dealt with in different ways according to the grades, personal, course and vocational need of students. Further, the material, suggestions and exercises provided are not intended to be exhaustive; once embarked on the Programme it should be possible for teachers and students in discussion to introduce other topics, reading passages, material for examination and analysis, and to devise exercises going outside and beyond anything contained in the Programme.

It is hoped that the Programme will be used progressively and selectively. The sections are written in a sequence and as may be seen from the detail of lay-out in the Introduction it is assumed that students will normally give attention to work in the early sections before going on to later sections, but this is not essential. There are appropriate sectional cross-references thus enabling students to relate their work in one area of communication studies to others, starting from the area which seems most suitable according to their needs.

Counties Technical Examinations Council, and the Yorkshire Council for Further Education.

\section{Acknowledgements}

The author and publisher wish to thank the following for permission to use copyright material:

Faber \& Faber Ltd for Peter Nichols - a short extract from $A$ Day in the Death of Joe Egg; W. H. Auden - 'The Unknown Citizen' and 'Night Mail' from Collected Shorter Poems 1927-1957; William Golding - opening paragraph from Pincher Martin. A. P. Watt \& Son for H. G. Wells passage from The New Machiavelli (by permission of the Estate of the late H. G. Wells). Associated Book Publishers Ltd for L. S. Stebbing - extract 'Statements' from An Elementary Logic (acknowledgement to Methuen \& 
Co. Ltd); W. T. Waugh - extract from A History of Europe 1378-1495 (acknowledgement to Methuen \& Co. Ltd); Elwyn Edwards - passage from Information Transmission (acknowledgement to Chapman \& Hall Ltd). Hamish Hamilton Ltd for Rachel Carson - passage from Silent Spring, Copyright the Estate of Rachel Carson 1962. George Weidenfeld \& Nicolson for Sir Leon Bagrit - passage from The Age of Automation. Heinemann Educational Books Ltd for C. W. Park - passage, table and graph from The Population Explosion. William Heinemann Ltd for John Galsworthy - passage from A Man of Property. J. M. Dent \& Sons Ltd for Dylan Thomas - passage from Under Milk Wood (acknowledgement to the Trustees for the Copyrights of the late Dylan Thomas). John Murray for John Betjeman - poem 'The Village Inn'. Laurence Pollinger Ltd for D. H. Lawrence - extract 'Man is a Hunter' from Phoenix (acknowledgement to Laurence Pollinger Ltd and the Estate of the late Mrs Frieda Lawrence). David Higham Associates Ltd for Naomi Mitchison - story 'On an Island' from Five Men and a Swan. Business Books Ltd for A. N. Neal - diagram of small-capacity incinerator and small section of accompanying text, and an extract on 'Cullet'. The Bodley Head for Michael Sholokov - passage from And Quiet Flows the Don (acknowledgement to Putnam Ltd). The Curator, Silkeborg Museum, Jutland, Denmark, for passage from pamphlet by Kund Thorvildsen, The Tollund Man. Mr R. Fortescue-Foulkes for R. FortescueFoulkes - extract from booklet From Celtic Settlement to 20th-Century Hospital - 'The Story of Poltimore House'. Mark Paterson for Anna Freud - 'Adolescence', first published in vol. 13 of The Psychoanalytical Study of the Child, reprinted in volume form in Research at the Hampstead Child Therapy Clinic and Other Papers. Longman Group Ltd for Robert Millar passage 'Class in British Society' from The New Classes. Hutchinson Publishing Group for S. Hall and P. Whannel - passage from The Popular Arts. R. A. S. Holidays Ltd for passage from 1969 brochure. Book of Life, Marshall Cavendish Ltd for passage from Book of Life, 'on Adoption'. World Survey for passage from Pamphlet 35, Race. The Royal Society of Arts for Malcolm Ford - passage from New Zealand's Fieldwork in the Antarctic. Oxfam for paragraphs from circular letter. Her Majesty's Stationery Office for paragraphs from Report of the Committee on the Age of Majority (Latey). Table from official leaflet Teaching Fire Prevention reproduced with the permission of the Comptroller of Her Majesty's Stationery Office. Evans Bros Ltd for Ewan Montague - extract from The Man Who Never Was. The Ramblers' Association for Letter by Mr Alex Lyon from Rucksack (Winter 1972). British Railways Board for public notice of withdrawal of services between Rugby and Nottingham. Icelandic Embassy for material from booklet published by the Government of Iceland, Fisheries Jurisdiction of Iceland (July 1971). British Tourist Authority for map of Northumbria from publication Northumbria - the Holiday Kingdom. Joan P. Page \& Co. Ltd for circular letter. Commercial Union Assurance Co. Ltd for table of statistics taken from leaflet on housing costs. Dryad Ltd for Charles Crampton - passage 'Waste Paper Basket' from Canework. The Speaker, House of Commons, for Drawing by Osbert Lancaster used as Christmas Card by Members of Parliament 1972. 
National Dairy Council for advertisement 'Milk helps you stand up to seeing the New Year in'. Penguin Books Ltd for Dostoevsky - passage from The Brothers Karamazov, translated by David Magarshack, copyright David Magarshack 1958. George Allen \& Unwin Ltd for J. R. R. Tolkien passage from Lord of the Rings for Kallas Nickels - map from Finland Ambassador College for two satellite pictures. Mr Reginald Haggar for monochrome print of water-colour 'The Last Firing - Longton'. The Guardian for 'Return from Vietnam' - report, 7 Dec. 1972, and an exchange of Open Letters - Mr Brown to Mr Wilson. Dr John Frears for article 'Blanc Vote' from The Guardian (6 June 1973). Doubleday \& Co. Inc. for David Shub - extract from Lenin. Cassell \& Co. Ltd for W. S. Churchill passage from The Second World War, volume v. Hutchinson Publishing Group Ltd - several paragraphs on the great letter-writers from Letters to Gog and Magog by Frank Swinnerton. Leicestershire and Rutland Constabulary for two posters on crime-prevention. Curtis, Brown Ltd for Auden and Isherwood - Letters from Iceland (extract). The Viking Press Inc. for letter from Nicola Sacco to his son, from The Letters of Sacco and Vanzetti. Drive AA Motorist Magazine for tables from the New Year 1972 edition of Drive. The British Museum for first paragraph from item 50, from The Treasures of Tutankhamun, and from Times Newspapers Ltd. by I. E. S. Edwards, published by Michael Joseph Ltd.

$\begin{array}{ll}\text { Loughborough Technical College } & \text { F. E. F. }\end{array}$ 


\section{INTRODUCTION}

In the world of business, industry, administration, social and political affairs written and spoken communication are the main means of ensuring that work is properly organised and carried out. Poor writing and speech are a recipe for irritation, confusion and high costs; good written and spoken communication certainly make business easier, pleasanter and more efficient.

The Programme is concerned with some of the main problems of communication, especially written communication - though frequently we shall be using words such as 'telling', 'speaking', 'listening' and 'audience'. In a sense all these words are necessary in any discussion about communication, since all communication consists of development from, alternatives to, or substitutes for, clear speech and hearing. But often in such discussions the words are not to be taken quite literally.

Attention is drawn to some of the main difficulties of saying (writing) whatever has to be said to the person or persons who must be spoken to for whatever purpose; and the Programme suggests some of the ways of avoiding the failures in communication that so often clog business and administration. It reminds students of some basic principles (if not 'rules') to be observed in learning how to communicate efficiently, especially in writing; and it draws to their attention some of the conventions, styles and routines of communication with which they may be expected to be familiar when they seek employment in business, administration and the like.

Several important assumptions are made about those students who are likely to use this Programme. These are that:

- they want to learn to communicate;

- however uncertain and vague they may feel about their ultimate occupations or careers, they wish to do reasonably well in whatever field they eventually choose;

- they have enjoyed a reasonably effective education so far (even if they were, at the last, anxious to leave school) and that they have learned most of the 'basics' about expressing themselves in speech and writing, at least to the point where they feel the need to do better;

- they are willing to make an effort; that they do not expect to become efficient just by waiting and hoping; that they do not subscribe to Dogberry's dictum: 'to write and read comes by nature'; 
- they are not content with just getting by or of being no better than anyone else. As Phyllis complacently put it:

'I can spell all the words that I use, And my grammar's as good as my neighbour's.'

All the work suggested in the Programme has been conceived in terms of a set of four basic principles of effective communication, applicable indeed to all kinds of communication whether or not in speech or writing. These principles may be expressed in the form of questions to be asked on every occasion that communication is considered or attempted:

FROM WHOM, Tо Wном? - every act of communication is from someone to someone, and exactly who makes a difference to the nature, form, tone and timing of the communication itself;

WHAT? - the message itself may be simple, complex, direct, indirect. It must be clear (this does not always mean it must be instantly obvious to any dim-wit) both to sender and receiver what the message is intended to be;

How? - by what means, in what form of words, in what tone, what manner, what 'code' or convention is the message transmitted? Is it the right or most appropriate method? Is it sent at the right time?

With What EFfect? - this is the most difficult of all the questions to answer. The sender of a message cannot know what the effect is going to be until it has been received; but he can, and should, anticipate. Experience should tell him what kinds of things he can do to achieve the effect he intended. He should never be in the unfortunate predicament of having to say, after some disastrous misunderstanding following his inept piece of communication: 'That isn't what I meant.'

These questions can and should be asked in every exercise suggested by the Programme. Work is arranged is such a way that the student is encouraged to ask these questions all the time.

It is not intended that students using the Programme should work their way systematically from one end to the other - unless, of course, they actually wish to. Discussion moves from the ways of obtaining, comprehending, interpreting and applying information through to methods of handling digested information, presentation and transmission. It concludes with a return to some of the more general and familiar issues of 'self-expression', essay-writing and the like (to whom?). This is not to suggest that self-expression is something different from the earlier, hard practical matters. The 
whole Programme is about self-expression, which, for the purposes of the underlying argument, is making personal, original, distinctive use of whatever ideas and information come the writer's way. Originality has nothing 'airy-fairy' about it; it is the confident process of taking possession.

Work is arranged into eight main areas of interest and activity:

1 Getting and Giving Information

2 GetTing INFORMATION FROM ReAding

3 Other SOURCES OF INFORMATION

4 Reports: Verbatim and SUMmary

5 Reports: Descriptive, Analytical, Explanatory

6 Communication Direct: Letters, Memoranda and Telegrams

7 Communication Direct: Notices, Announcements, INSTRUCTIONS, ADVERTISEMENTS

8 EXPRESSIVE WRITING

Each main study area has a number of sections, directing attention to particular problems and forms. Each section is introduced with a short exposition, hopefully drawing attention to matters that have been learned earlier in the Programme or earlier in the student's school career.

The sections are divided into subsections, each with its short expository introductions, followed by suggestions for work under the headings:

Activity AND Discussion - suggestions for individual and group activity and discussion around the topic just introduced.

CRITICISM IN PRACTICE - mainly examples and passages for study, analysis and discussion, often followed by detailed 'comprehension' or short critical exercises.

EXERCISES - usually at the end of the main section, suggesting a variety of assignments related to the work done in all the subsections. Some of these will be typical examination questions.

Not all of the subsections have both Activity and Discussion and Criticism in Practice, and there is inevitable overlap between the kinds of work contained in these subsubsections.

The Programme is not intended as an 'examination course' and should be of interest to a wide range of students who include English and Communication in their courses, particularly those who are expecting to work in offices, public administration, and industrial 
management at almost any level, but do not necessarily have to face an examination in English.

It is hoped that students will find the reading passages interesting, even entertaining, and that the exercises and suggestions for activity will appeal to them as having demonstrable relevance to real life. More important still, the Programme will only have succeeded in its purpose if students find themselves taking more and more critical interest in communication as it is actually practised in business, industry, and social and public affairs. There is in the outside world much more of the right kind of material, problems and ideas for the keen student of communication to grapple with than can ever be contained, or even successfully illustrated, in a textbook or teaching and study Programme.

\section{ACTIVITY AND DISCUSSION}

1. Examine the Introduction you have just read in terms of the four principles suggested in the text:

- Who is 'speaking' to whom?

- What is the main argument?

- How is it done? Is the approach right? Are the right words used?

- What is the effect of the passage on you?

2. Consider the questions:

Would the Introduction you have just read be more use as a Conclusion? Does it help to have things explained in this general way before starting on the main part of the work?

3. Discuss the assumptions made about the kinds of students the author thinks will benefit from this course.

Is he justified in making such assumptions?

Suppose some or all of the assumptions are not correct so far as you are concerned. What do you think ought to be done about it? How would you tackle the job?

4. Discuss the proposition that all good composition, even on the most routine subjects, is original and 'self-expressive' in some degree.

If you have reservations about this, you might consider whether or not a computer could make a better job of some of the communication tasks that clerks and other office workers are often called on to do. What kinds of tasks?

5. Who are Dogberry and Phyllis, and where, when and to whom did they make the remarks referred to? 